\begin{tabular}{|l|l|l||}
\hline \multicolumn{2}{|c|}{ PublisherInfo } \\
\hline \hline PublisherName & $:$ & BioMed Central \\
\hline \hline PublisherLocation & $:$ & London \\
\hline \hline PublisherImprintName & $:$ & BioMed Central \\
\hline \hline
\end{tabular}

\title{
Second RNAi pathway emerges
}

\begin{tabular}{|l|l|l||}
\hline \multicolumn{2}{|c|}{ ArticleInfo } \\
\hline \hline ArticleID & $:$ & 4993 \\
\hline \hline ArticleDOI & $:$ & $10.1186 /$ gb-spotlight-20040817-01 \\
\hline \hline ArticleCitationID & $:$ & spotlight-20040517-01 \\
\hline \hline ArticleSequenceNumber & $:$ & 56 \\
\hline \hline ArticleCategory & $:$ & Research news \\
\hline ArticleFirstPage & $:$ & 1 \\
\hline \hline ArticleLastPage & $:$ & 3 \\
\hline \hline & & RegistrationDate : 2004-8-17 \\
\hline ArticleHistory & $:$ & OnlineDate \\
\hline \hline ArticleCopyright & $:$ & BioMed Central Ltd2004-8-17 \\
\hline \hline ArticleGrants & $:$ & \\
\hline \hline ArticleContext & $:$ & 130595511 \\
\hline \hline
\end{tabular}




\section{Jack Lucentini}

Email: Jekluc@aol.com

The publication of a study in Nature (Nature 2004, DOI:10.1038/nature02889) - combined with a similar study in Science earlier this month - could force a reexamination of how RNA interference (RNAi) works, said several in the field not involved in the studies. While RNA had been known to silence genes post-transcriptionally, researchers found that it does so in a different way, found previously in plants, at the transcriptional level in human cells.

"This is a strong, strong suppressive pathway," said the lead author of the Science paper, Kevin Morris, of the University of California, San Diego. Morris' team found that SiRNAs targeting the promoter of a green fluorescent protein gene transfected into human fibroblasts reduced its mRNA levels by about $70 \%$.

Separately, University of Tokyo researchers report in Nature that exploiting the same basic pathway in mammary cells, they sliced two endogenous genes' mRNA levels by more than $80 \%$. One gene was a tumor-promoting oncogene, erbB2; transcriptional RNAi significantly reduced cell proliferation in this case, they wrote, suggesting therapeutic potential. Therapies might exploit both silencing pathways simultaneously, lead author Kazunari Taira told us: "It's very easy to mix two different siRNAs."

This second pathway could open the way for longer-lasting effects, new therapeutic strategies, and evolutionary insights, researchers said. It could be "an entirely new and important mechanism for regulating DNA expression" in mammals, said Duke University's Bryan Cullen, who was not involved in the studies. Edward Whang of Brigham and Women's Hospital, Boston, who also was not involved in the studies, told us the findings may recast RNAi as an unexpectedly complex system, with greater potential for unintended consequences than suspected earlier.

RNAi had been known to work transcriptionally in plants, by methylating gene promoters with sequences complementing the RNAs. The new studies show this pathway, possibly an adaptation to suppress junk genes, is "conserved in human cells," Morris told us.

Cullen said although he was one of many who doubted this was so - due to past findings suggesting otherwise - the new research has made him reconsider. Cullen and others said it is significant that the transcriptional pathway apparently involves methylation. Cells typically pass this DNA-regulating modification to daughter cells, possibly permitting more lasting therapies. The other pathway works relatively transiently.

Transcriptional RNAi also presents challenges. Three questions it raises, Morris said, are whether it works on every promoter; how to efficiently deliver drugs into nuclei, where genes reside; and how to reverse its effects. Whang noted that "the more complex and varied the mechanisms by which siRNA induces gene silencing, the more potential there is for unintended consequences and, perhaps, off-target silencing" - pitfalls for studies and therapies alike.

Beyond the pitfalls, the findings may offer new insights into life, Morris said. For example, an evergrowing list of RNA's identified capabilities could boost a widely held hypothesis that RNA was the original genetic molecule. This "says a whole lot about our evolutionary origins," he said. 
Last week, Philadelphia-based Acuity Pharmaceuticals announced it had become the first company to request regulatory approval for RNAi clinical trials, targeting wet age-related macular degeneration.

\section{References}

1. Nature, [http://www.nature.com/nature/]

2. Small interfering RNA-induced transcriptional gene silencing in human cells

3. Kazunari Taira, [http://www.adm.u-tokyo.ac.jp/IRS/IntroPage_E/intro16382367_e.html]

4. Bryan R. Cullen, [http://www.hhmi.org/research/investigators/cullen_bio.html]

5. Acuity Pharmaceuticals, [http://www.acuitypharma.com/] 